\title{
PENGARUH KUALITAS PELAYANAN PAJAK, KEWAJIBAN MORAL, DAN \\ SANKSI PAJAK TERHADAP KEPATUHAN WAJIB PAJAK BADAN (Studi \\ Empiris di Kantor Pelayanan Pajak Pratama Kebayoran Baru Tiga)
}

\author{
Natrion \\ Nurianti \\ Fakultas Ekonomi, Universitas Satya Negara Indonesia, \\ Jakarta 2018 \\ Natriont@yahoo.com \\ Nuriantiiz28@gmail.com
}

ABSTRACT

The purpose of this research is to know the influence of the quality of service, moral obligation, and tax sanctions, corporate on taxpayer compliance. This researcher consists of three independent variables and one dependent variable, the independent variables in this research are the quality of tax service, moral obligation, and tax sanction. While the dependent variable in this study is taxpayer compliance. The data of this research are primary data obtained through the distribution of questionnaires. The sampling technique used convenience sampling method, and the results of this research indicate that the quality of tax service does not affect the compliance of corporate taxpayers, While the moral obligations, and tax sanctions affect the compliance of corporate taxpayers

Key words: quality of tax service, moral obligations, tax sanctions, compliance of corporate taxpayers 


\begin{abstract}
ABSTRAK
Penelitian ini adalah untuk mengetahui pengaruh kualitas pelayanan pajak, kewajiban moral, dan sanksi pajak terhadap kepatuhan wajib pajak badan. Penelitian ini terdiri atas tiga variabel independen dan satu variabel dependen. Variabel independen dalam penelitian ini adalah kualitas pelayanan pajak, kewajiban moral, dan sanksi pajak. Sedangkan variabel dependen dalam penelitian ini adalah kepatuhan wajib pajak. Data penelitian ini adalah data primer yang diperoleh melalui penyebaran kuesioner. Teknik pengambilan sampel menggunakan metode convenience sampling, dan hasil penelitian ini menunjukkan bahwa kualitas pelayanan pajak tidak berpengaruh terhadap kepatuhan wajib pajak badan. Sedangkan kewajiban moral, dan sanksi pajak berpengaruh terhadap kepatuhan wajib pajak badan.
\end{abstract}

Kata Kunci: Kualitas Pelayanan, Kewajiban Moral, Sanksi Pajak, Kepatuhan Wajib Pajak Badan 


\section{PENDAHULUAN}

Pajak merupakan iuran wajib pajak kepada negara yang dipungut secara sah oleh pemerintah berdasarkan undang-undang, dan sampai saat ini pajak masih menjadi sumber pendapatan negara yang digunakan untuk membiayai pengeluaranpengeluaran negara. Dan untuk perpajakan Indonesia menganut asas perpajakkan self assesments system, self assesments system merupakan asas perpajakkan dimana wajib pajak diberikan kepercayaan penuh untuk menghitung, membayar dan melaporkan jumlah pajak yang seharusnya terhutang berdasarkan peraturan perundang-undangan perpajakkan. Dalam sistem tersebut saat bergantung pada faktor kesadaran wajib pajak dalam kepatuhan membayar pajak.

Kepatuhan dalam wajib pajak dapat dikatakan sebagai persyaratan pelaporan pajak dimana wajib pajak mengajukan dan melaporkan kewajiban sesuai dengan peraturan yang berlaku (Devos,2009). Untuk mengatasi kepatuhan dalam wajib pajak agar tidak terjadinya tunggakkan pajak yang akan terjadi disetiap tahunnya diperlukan kualitas pelayanan, kewajiban moral dari wajib pajak dan sanksi perpajakkan yang dibuat dari pajak.

Kualitas pelayanan dinilai sebagai perbandingan antara harapan yang diinginkan oleh pelanggan dengan penilaian mereka terhadap kinerja aktual dari suatu penyediaan layanan (Cronin,2002). Pelayanan terjadi melalui interaksi manusia, kontak antara layanan pelanggan dengan karyawan selama pelayanan berlangsung sangat menentukan tingkat kualitas pelayanan yang disampaikan kepada pelanggan (Muchtar Hidayat,2010). Selain itu harapan dan keinginan masyarakat selaku wajib pajak harus sesuai dengan standar yang telah ditentukan agar terciptanya rasa puas dari masyarakat/wajib pajak, karna jika pelanggan puas dengan pelayanan dan kinerja yang ditawarkan atau yang disajikkan setiap organisasi/perusahaan maka pelanggan akan membalas dengan memberikan penilaian yang tinggi (Purwanto, 2004). 
Upaya lain dalam meningkatkan kepatuhan wajib pajak adalah dengan meningkatkan kewajiban moral wajib pajak. Kewajiban moral adalah moral yang berasal dari masing-masing individu yang kemungkinan orang lain tidak memilikinya (Ajsen,2002). Menurut Wenzel (2005) moral wajib pajak, etika dan norma sosialnya sangat berpengaruh terhadap perilaku dari wajib pajak. Kewajiban moral yang lebih kuat dari wajib pajak akan mampu meningkatkan tingkat kepatuhanya (Ho, 2009). kewajiban moral merupakan norma individu yang dimiliki seseorang dimana tingkat kepatuhan pajak akan menjadi lebih tinggi ketika wajib pajak memiliki kewajiban moral yang lebih kuat (Ajzen, 2002).

Sanksi pajak merupakan alat pencegah agar wajib pajak tidak melanggar norma perpajakan. Setiap jenis pelanggaran pajak mulai dari yang tingkatannya paling kecil sampai yang paling berat sudah tersedia ancaman sanksinya. Hal ini semakin tercermin pasca amandemen undang-undang ketentuan umum dan tata cara perpajakan (UU Nomor 28 Tahun 2007) yang berhasil menggulirkan ketentuan-ketentuan baru menyangkut sanksi seputar pelanggaran kewajiban wajib pajak dan fiskus. Peraturan itu dibuat untuk meminimalisir tindakan pelanggaran hukum yang dilakukan baik oleh wajib pajak maupun fiskus. Penegakkan hukum secara adil oleh aparat pajak diperlukan bagi wajib pajak yang lalai dalam membayar pajak sehingga diharapkan mampu mendorong motivasi wajib pajak dalam membayar pajak. Oleh karena itu, ketegasan sanksi perpajakan sangat diperlukan agar kesadaran masyarakat dalam membayar pajak dapat meningkat.

Dan dari hasil penelitian ini juga konsisten dengan penelitian terdahulu yang dilakukan oleh I Putu Adi Putra Sanjaya,dkk(2014) bahwa kewajiban moral berpengaruh secara positif terhadap kepatuhan wajib pajak badan. Dan hasil Hasil penelitian ini juga sejalan dengan hasil penelitian Nurulita Rahayu,dkk(2017) dan I Putu Adi Putra Sanjaya(2014), menyatakan bahwa sanksi pajak berpengaruh positif terhadap kepatuhan wajib pajak. Semakin tinggi ketegasan sanksi pajak, maka kemauan wajib pajak untuk membayar pajak semakin tinggi dan akan meningkatkan kepatuhan wajib pajak. 
Pada Hasil penelitian kualitas pelayanan pajak tidak berpengaruh terhadap kepatuhan wajib pajak. Semakin rendahnya kualitas pelayanan kantor pajak akan semakin menurunnya kepatuhan wajib pajak. sejalan dengan hasil penelitian Iva Farida Hidayati(2014) serta Jessica Novia Susanto(2013).

\section{LANDASAN TEORI}

Definis pajak menurut Prof. Dr. Rochmat Soemitro, S.H., Pajak adalah iuran rakyat kepada kas negara berdasarkan undang-undang (yang dapat dipaksakan) dengan tiada mendapat jasa timbal (kontrapretasi) yang langsung dapat ditunjukkan dan yang digunakan untuk membayar pngeluaran umum.

Menurut Prof Dr. P. J. A. Andriani, pajak yaitu iuran kepada Negara (yang dapat dipaksakan yang terutang oleh yang wajib membayarnya menurut peraturan-peraturan, dengan tidak mendapat prestasi kembali, yang langsung dapat ditunjukan, dan yang gunanya adalah untuk membiayai penegluaran-pengeluaran umum berhubungan dengan tugas Negara yang menyelenggarakan pemerintah.

\section{Kualitas Pelayanan pajak}

kualitas pelayanan dapat dinilai sebagai perbandingan antara harapan yang diinginkan oleh pelanggan dengan penilaian mereka terhadap kinerja aktual dari suatu penyediaan layanan (Cronin,1992). Pelayanan terjadi melalui interaksi manusia, kontak antara layanan pelanggan dengan karyawan selama pelayanan berlangsung sangat menentukan tingkat kualitas pelayanan yang disampaikan kepada pelanggan (Muchtar Hidayat,2010). Selain itu harapan dan keinginan masyarakat selaku wajib pajak harus sesuai dengan standar yang telah ditentukan agar terciptanya rasa puas dari masyarakat/wajib pajak. (I Putu:2014:211) 


\section{Kewajiban Moral}

Kewajiban moral adalah moral yang berasal dari masing-masing individu yang kemungkinan orang lain tidak memilikinya (Ajsen,2002). Menurut Wenzel (2005) moral wajib pajak etika dan norma sosialnya sangat berpengaruh terhadap perilaku dari wajib pajak. Kewajiban moral yang lebih kuat dari wajib pajak akan mampu meningkatkan tingkat kepatuhanya.

Etika adalah sebagai pandangan manusia dalam berperilaku menurut ukuran dan nilai yang baik (Simorangkir). Norma sosial yaitu suatu bentuk tatanan hidup yang berisikan aturan-aturan dalam bersosialisasi di masyarakat (Nurdiaman).

\section{Sanksi Pajak}

Sanksi pajak merupakan jaminan bahwa ketentuan peraturan perundang undangan perpajakan (norma perpajakan) akan dituruti/ditaati/dipatuhi, dengan kata lain sanksi perpajakan merupakan alat pencegah agar wajib pajak tidak melanggar norma perpajakan, mardiasmo(2009). Setiap jenis pelanggaran pajak mulai dari yang tingkatannya paling kecil sampai yang paling berat sudah tersedia ancaman sanksinya. 


\section{METODOLOGI PENELITIAN}

\section{Jenis Penelitian dan Populasi Sampel}

Data yang digunakan dalam penelitian ini yaitu data primer. Data primer adalah data penilitian yang diperoleh secara langsung dari sumber asli yang secara khusus dikumpulkan untuk menjawab kuesioner atau berkomunikasi langsung kepada responden melalui kuesioner yang langsung diberikan kepada responden. Data yang diperoleh langsung dari wajib pajak orang pribadi yang menyelenggarakan pembukuan yang terdaftar di KPP Pratama Kebayoran Baru Tiga.

\section{Teknik Pengembalian Sampel}

Sampel yaitu sebagian dari jumlah karakteristik yang dimiliki oleh populasi tersebut, ataupun bagian kecil dari anggota populasi yang diambil menurut prosedur tertentu sehingga dapat mewakili populasinya. Penentuan jumlah sampel mengguankan rumus slovin, dalam peneliti akan menggunakan pengambilan sampel dengan metode convenience sampling yaitu pengambilan sampel secara acak. Elemen populasi yang dipilih sebagai subjek sampel adalah tidak terbatas sehingga peneliti memiliki kebebasan untuk memilih sampel yang paling cepat dan murah

\section{Teknik Pengumpulan Data}

1. Teknik Pengumpulan Data

Ada dua cara metode pengumpulan data yang digunakan dalam penelitian ini yaitu :

a. Metode Penelitian Kepustakaan (Library Research) adalah penelitian dengan mengumpulkan data dengan cara membaca dan mempelajari buku-buku yang ada dan sumber data yang lainnya berkaitan dengan pembahasan masalah yang dibutuhkan.

b. Metode Penelitian Lapangan (Field Research) adalah metode dengan mengunjungi objek penelitian guna memperoleh data-data yang diperlukan untuk penyusunan penelitian tersebut. 
2. Teknik mengumpulkan data dilakukan dengan metode :

a) Wawancara

Yaitu percakapan antara dua orang atau lebih, yang dilakukan dengan cara menyampaikan sejumlah pertanyaan dari pewawancara kepada narasumber.

b) Observasi

Yaitu proses pengamatan dan pencatatan secara sistematis mengenai gejalagejala yang diteliti

c) Instrumen yang digunakan dalam penelitian ini berupa kuesioner yang akan diberikan kepada wajib pajak yang melaporkan pajak di KPP Pratama Kebayoran Baru Tiga.

\section{Teknik Analisis Data}

Teknik analisis data yaitu dengan menghitung profil responden, Uji kualitas data, uji asumsi klasik, Analisis Kolerasi, dan pengujian hepotesis yang berisi regresi berganda, uji t, uji f, dan uji determinasi.

\section{Analisis Hasil dan Pembahasan}

Kuesioner yang disebar sebanyak 110 kuesioner, tetapi kuesioner yang dapat diolah sebanyak 98 dan tidak dapat diolah sebanyak 12 kuesioner. Sebanyak 12 kuesioner yang tidak kembali disebabkan karena waktu penelitian bertepatan dengan waktu wajib pajak sedang melakukan pelaporan pajak atau melakukan pelayanan di kantor pajak, dan setelah dilakukan beberapa uji data tersebut dalam penelitian ini bisa dilihat untuk mengetahui pengaruh atau tidaknya suatu variabel tersebut bisa dilihat dari data uji regresi berganda, uji t dan uji f. 


\section{Uji Regresi Berganda}

\section{Coefficients $^{\mathrm{a}}$}

\begin{tabular}{|l|l|l|l|l|l|}
\hline Model & \multicolumn{2}{|l|}{$\begin{array}{l}\text { Unstandardized } \\
\text { Coefficients }\end{array}$} & $\begin{array}{l}\text { Standardize } \\
\mathrm{d} \\
\text { Coefficients }\end{array}$ & $\mathrm{t}$ & \multirow{2}{*}{} \\
& $\mathrm{B}$ & Std. Error & Beta & \\
\cline { 2 - 5 } & 5.117 & 1.689 & & 3.030 & .003 \\
Kualitas & .010 & .027 & .041 & .389 & .698 \\
Kewajiban & .202 & .076 & .277 & 2.655 & .009 \\
Moral & & & & & \\
Sanksi Pajak & .409 & .118 & .337 & 3.469 & .001 \\
\hline
\end{tabular}

a. Dependent Variable: Kepatuhan Pajak

diperoleh dari koefisien regresi di atas, maka dapat dibuat suatu persamaan regresi linear berganda sebagai berikut :

$\mathrm{Y}=5,117+0,010 \mathrm{X} 1+0,202 \mathrm{X} 2+0,409 \mathrm{X} 3+e$

Persamaan regresi linear di atas dapat dijelaskan sebagai berikut :

1. Nilai konstanta sebesar 5,117 artinya jika variabel Kualitas Pelayanan (X1), Kewajiban Moral (X2), dan Sanksi Pajak (X3) memiliki nilai sebesar 0 maka variabel Kepatuhan Wajib Pajak (Y) akan memiliki nilai sebesar 5,117.

2. Koefisien regresi variabel Kualitas pelayanan (X1) sebesar 0,010 artinya jika kualitas pelayanan mengalami kenaikan 1 (satu) satuan, maka akan menurunkan kepatuhan wajib pajak sebesar 0,010 atau $1 \%$.

3. Koefisien regresi variabel Kewajiban Moral (X2) sebesar 0,202 namun jika Kewajiban moral mengalami kenaikan 1 (satu) satuan, maka akan menaikkan kepatuhan wajib pajak sebesar 0,202 atau $20,2 \%$. 
4. Koefisien regresi variabel Sanksi Pajak (X3) sebesar 0,409 artinya jika Sanksi Pajak mengalami kenaikan 1 (satu) satuan, maka akan menaikkan kepatuhan wajib pajak sebesar 0,409 atau 40,9\%.

\section{Uji t}

\section{Coefficients $^{\mathrm{a}}$}

\begin{tabular}{|c|c|c|c|c|c|c|}
\hline \multirow{2}{*}{\multicolumn{2}{|c|}{ Model }} & \multicolumn{2}{|c|}{$\begin{array}{l}\text { Unstandardized } \\
\text { Coefficients }\end{array}$} & \multirow{2}{*}{\begin{tabular}{|l}
$\begin{array}{l}\text { Standardized } \\
\text { Coefficients }\end{array}$ \\
Beta
\end{tabular}} & \multirow[t]{2}{*}{$\mathrm{T}$} & \multirow[t]{2}{*}{ Sig. } \\
\hline & & B & Std. Error & & & \\
\hline \multirow{5}{*}{1} & (Constant) & 5.117 & 1.689 & & 3.030 & .003 \\
\hline & Kualitas & .010 & .027 & .041 & .389 & .698 \\
\hline & Kewajiban & .202 & .076 & .277 & 2.655 & .009 \\
\hline & Moral & & & & & \\
\hline & Sanksi Pajak & .409 & .118 & .337 & 3.469 & .001 \\
\hline
\end{tabular}

a. Dependent Variable: Kepatuhan Pajak

dijelaskan mengenai pengaruh secara parsial masing-masing variabel bebas sebagai berikut :

\section{Pengaruh Kualitas Pajak (X1) terhadap Kepatuhan Wajib Pajak} (Y)

Dari Tabel 4.21 tersebut menunjukkan bahwa $t_{\text {hit }}$ variabel kualitas pelayanan pajak sebesar 0,389 dimana $t_{\text {hit }}$ bernilai lebih besar dari $t_{\text {tabel }}$ sebesar $1.98552(0,389<1,98552)$ dan tingkat signifikan sebesar $0,698(0,698>0,05)$. Dengan demikian, keadaan tersebut dapat disimpulkan bahwa Ho diterima dan Ha ditolak. Hal ini berarti bahwa kualitas pelayanan pajak tidak berpengaruh terhadap Kepatuhan Wajib Pajak. 


\section{Pengaruh Kewajiban Moral (X2) terhadap Kepatuhan Wajib Pajak}

(Y)

Dari Tabel 4.21 tersebut menunjukkan bahwa $t_{\text {hitun }}$ variabel Kewajiban Moral sebesar 2,655 dimana $t_{\text {hitu }}$ bernilai lebih besar dari $t_{\text {tabel }}$ sebesar $1,98552(2,655>1,98552)$ dan tingkat signifikan sebesar $0,009(0,009<0,05)$. Dengan demikian, keadaan tersebut dapat disimpulkan bahwa Ho ditolak dan Ha diterima. Hal ini berarti bahwa Kewajiban Moral berpengaruh positif terhadap kepatuhan wajib pajak.

\section{Pengaruh Sanksi Pajak (X3) terhadap Kepatuhan Wajib Pajak (Y)}

Dari Tabel 4.21 tersebut menunjukkan bahwa $t_{\text {hitu }}$ variabel Sanksi Pajak sebesar 3,469 dimana $t_{\text {hitu }}$ bernilai lebih besar dari $t_{\text {tabel }}$ sebesar $1.98552(3,469>1,98552)$ dan tingkat signifikan sebesar 0,001 $(0,001<0,05)$. Dengan demikian, keadaan tersebut dapat disimpulkan bahwa Ho ditolak dan Ha diterima. Hal ini berarti bahwa sanksi pajak berpengaruh positif terhadap kepatuhan wajib pajak.

\section{Uji F}

ANOVA $^{\mathrm{a}}$

\begin{tabular}{|ll|l|l|l|l|l|}
\hline \multicolumn{2}{|l|}{ Model } & $\begin{array}{l}\text { Sum } \\
\text { Squares }\end{array}$ & Df & $\begin{array}{l}\text { Mean } \\
\text { Square }\end{array}$ & F & Sig. \\
\hline \multirow{4}{*}{$\begin{array}{l}\text { Regressi } \\
\text { on }\end{array}$} & 188.286 & 3 & 62.762 & 12.328 & .000 \\
& $\begin{array}{l}\text { Residual } \\
\text { Total }\end{array}$ & 478.557 & 94 & 5.091 & & \\
& 666.843 & 97 & & & \\
\hline
\end{tabular}

a. Dependent Variable: Kepatuhan Pajak

b. Predictors: (Constant), Sanksi Pajak, Kewajiban Moral, Kualitas 
dari tabel tersebut dapat dilihat nilai $t_{\text {hit }}$ sebesar 12,328 , jadi nilai $t_{\text {hitung }}>t_{\text {tabel }}$ atau 12,328 $>2,47$. Kesimpulannya data tersebut di uji secara simultan.

\section{Interprestasi Hasil Penelitian}

\section{Kualitas Pelayanan Pajak (X1) Terhadap Kepatuhan Wajib Pajak Badan(Y)}

Hasil pengujian statistik menunjukkan bahwa Kualitas pelayanan pajak memiliki nilai $t_{\text {hitung }}$ sebesar 0,389 dimana $t_{\text {hitun }}$ bernilai lebih kecil dari $t_{\text {tabel }}$ sebesar $1,98552(0,389<1,98552)$ dan tingkat signifikan sebesar 0,698. .Dapat dinyatakan bahwa kualitas pelayanan pajak tidak berpengaruh seterhadap kepatuhan wajib pajak badan.

Peningkatan Kualiatas pelayanan pajak di Kantor Pelayanan Pajak Pritama Kebayoran Baru Tiga tidak berpengaruh dikarenakan pelayanan yang diberikan fiskus tidak di berikan secara rutin atau maksimal dalam pelayanan terhadap wajib pajak, dan juga belum memenuhi sesuai kebutuhan atau harapan yang diinginkan wajib pajak sehingga wajib pajak tidak terlalu menganggap penting konsep pelayanan yang diberikan fiskus dan dan membuat kepercayaan wajib pajak menurun.

Hasil penelitian ini sejalan dengan hasil penelitian Iva Farida Hidayati(2014) serta Jessica Novia Susanto(2013) bahwa kualitas pelayanan pajak tidak berpengaruh terhadap kepatuhan wajib pajak. Semakin rendahnya kualitas pelayanan kantor pajak akan semakin menurunnya kepatuhan wajib pajak. 


\title{
Kewajiban Moral (X2) Terhadap Kepatuhan Wajib Pajak Badan (Y)
}

\author{
Hasil pengujian statistik menunjukkan bahwa kewajiban moral \\ memiliki nilai $t_{\text {hitung }}$ sebesar 2,655 dimana $t_{\text {hitu }}$ bernilai lebih besar dari \\ $t_{\text {tabel }}$ sebesar 1,98552 $(2,655>1,98552)$ dan tingkat signifikan sebesar \\ 0,009. Hal ini menyatakan bahwa Ho ditolak dan Ha diterima, artinya \\ bahwa kewajiban moral berpengaruh secara positif dan signifikan terhadap \\ kepatuhan wajib pajak. Kewajiban moral atau kesadaran moral wajib pajak \\ sangat berperan penting dalam kepatuhan wajib pajak sehingga wajib pajak \\ selalu patuh dalam melaporkan atau membayar pajak. Dengan memiliki \\ sikap tersebut, seorang wajib pajak tidak akan mudah dipengaruhi oleh \\ pihak lain yang dapat mengganggu kepatuhannya, karena ia hanya akan \\ melaksanakan dengan baik dalam melaporkan atau membayar pajak negara.
}

Hasil penelitian ini konsisten dengan penelitian terdahulu yang dilakukan oleh I Putu Adi Putra Sanjaya,dkk(2014) bahwa kewajiban moral berpengaruh secara positif terhadap kepatuhan wajib pajak badan.

\section{Sanksi Pajak (X3) Terhadap Kepatuhan Wajib Pajak (Y)}

Hasil pengujian statistik menunjukkan bahwa sanksi pajak memiliki nilai $t_{\text {hitung }}$ sebesar 3,469 dimana $t_{\text {hitun }}$ bernilai lebih besar dari $t_{\text {tabel }}$ sebesar 1,98552 $(3,469>1,98552)$ dan tingkat signifikan sebesar 0,001. Hal ini menyatakan bahwa Ho ditolak dan Ha diterima, artinya bahwa sanksi pajak berpengaruh secara positif dan signifikan terhadap kepatuhan wajib pajak. 
Dalam melaksanakan perpajakkan di suatu negara harus memiliki sanksi atau undang-undang dalam pembayaran pajak tersebut, agar jelas dan disiplin dalam melaksanakan pajak tersebut sehingga wajib pajak patuh akan peraturan atau tata tertib yang berlaku dalam pembayaran pajak atau pelaporan pajak tersebut, baik bagi wajib pajak perorang maupun wajib pajak badan.

Hasil penelitian ini sejalan dengan hasil penelitian Nurulita Rahayu,dkk(2017) dan I Putu Adi Putra Sanjaya(2014), menyatakan bahwa sanksi pajak berpengaruh positif terhadap kepatuhan wajib pajak. Semakin tinggi ketegasan sanksi pajak, maka kemauan wajib pajak untuk membayar pajak semakin tinggi dan akan meningkatkan kepatuhan wajib pajak. 


\section{Kesimpulan}

Berdasarkan hasil penelitian ini mengenai tentang Kualitas Pelayanan, Kewajiban Moral, dan Sanksi Perpajakkan terhadap Kepatuhan Wajib Pajak Badan yang dikumpulkan pada Kantor Pelayanan Pajak Pratama Kebayoran Baru Tiga di wilayah Jakarta Selatan, maka dapat ditarik kesimpulan sebagai berikut :

1. Kualitas Pelayanan yang tidak berpengaruh terhadap kepatuhan wajib pajak sebesar 1\%. Berarti bahwa semakin rendah kualitas pelayanan yang dimiliki oleh suatu kantor pelayanan pajak, maka akan semakin menurun kepatuhan wajib pajak tersebut.

2. Kewajiban Moral berpengaruh positif dn signifikan terhadap kepatuhan wajib pajak, sebesar 20,2\%. Berarti adanya kewajiban moral atau kesadaran moral dari si wajib pajak meningkatkan kepatuhan wajib pajak badan.

3. Sanksi Pajak berpengaruh positif dan signifikan terhadap kepatuhan wajib pajak sebesar 40,9\%.. Berarti bahwa adanya sanksi pajak yang tegas, dapat meningkatkan kepatuhan wajib pajak yang baik.

4. Kualitas pelayanan pajak, kewajiban moral, dan sanksi pajak terhadap kepatuhan wajib pajak badan memiliki hubungan yang simultan, dann penelitian ini menunjukkan bahwa sebesar 25,9\% variabel Kualitas Pelayanan Pajak, Kewajiban Moral dan Sanksi Pajak secara simultan memiliki pengaruh yang cukup terhadap kepatuhan wajib pajak. Sedangkan sebagian sisanya sebesar $74,1 \%$ dapat dipengaruhi oleh variabel-variabel lain yang tidak termasuk dalam penelitian ini. 


\section{Saran}

Harapan peneliti pada penelitian selanjutnya yaitu dapat memperbaiki kekurangankekurangan dalam penelitian ini, diantaranya :

1. Sebaiknya penyebaran kuesioner tidak dilakukan pada waktu yang bertepatan dengan kesibukan para wajib pajak sedang melaporkan pajak, atau pada waktu yang lebih banyak agar efisien sampai pengembalian kuesioner. Sehingga kuesioner yang disebarkan mendapat tanggapan yang baik.

2. Melakukan penelitian dalam lingkup yang lebih luas sehingga dapat memperoleh data dan hasil analisa yang lebih akurat.

3. Menggunakan alat uji yang lebih baik lagi agar menghasilkan data yang akurat.

4. Melanjutkan dan mengulang kembali penelitian tentang pengaruh kualitas pelayanan, kewajiban moral dan sanksi perpajakan agar dapat diperoleh bukti empiris tambahan, apakah ketiga variabel tersebut memiliki korelasi.

5. Mengembangkan penelitian dengan menambahkan faktor-faktor dan variabel lain di luar model penelitian ini. Hal ini untuk menambah daftar literatur penelitian, serta mengembangkan ilmu pengetahuan secara akademik yang dapat digunakan sebagai referensi bagi peneliti selanjutnya.

6. Memperbaiki kualitas pelayanan pajak terhadap wajib pajak, dikarenakan semakin tinggi kualitas pelayanan pajak akan semakin tinggi kepatuhan wajib pajak tersebut. 